\title{
CORRELATES OF DEPRESSION IN THE SLOVENIAN WORKING POPULATION
}

\author{
Zalika KLEMENC-KETIŠ ${ }^{1,2}$ and Borut PETERLIN ${ }^{1,3}$

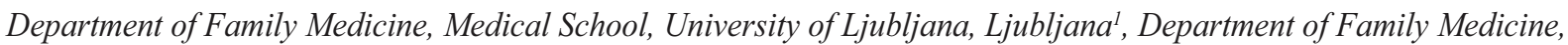 \\ Medical School, University of Maribor, Maribor ${ }^{2}$, Clinical Institute of Medical Genetics, University Medical Centre, \\ Ljubljana ${ }^{3}$, Slovenia
}

Received in February 2013

CrossChecked in May 2013

Accepted in October 2013

\begin{abstract}
This multicentre, cross-sectional observational study aimed to determine the prevalence of depression among the working population of Slovenia and identify factors correlating with higher prevalence of depression. It was conducted in three occupational medicine practices within major Slovenian primary health care centres. The study population consisted of 1,474 respondents $[73.7 \%$ of the invited participants, $889(60.3 \%)$ men and $585(39.7 \%)$ women with mean age of (40.5 \pm 9.8$)$ years] who visited these practices for their regular check-ups from November 2010 to June 2012 and were asked to fill in a self-developed questionnaire and score depression on the Zung's self-rating depression scale. According to the rating, 50 (3.4\%) respondents suffered from depression. In the multivariate analysis, depression correlated with the following independent variables: self-perceived exposure to chronic stress, positive family history of depression, and primary school education.
\end{abstract}

KEY WORDS: cross-sectional study, demographic data, family history, mental diseases, primary health care

Depression is a serious public health problem. Patients with depression (and other psychological problems) are frequent visitors of family practices all across Europe and therefore present a considerable burden to the healthcare system $(1,2)$. In addition, depression is a common comorbidity of chronic diseases that weakens the effects of treatment and disease management in chronic patients (3). However, anxiety disorders not only affect patient management, but also the well-being of the general population, as their prevalence is significant (4). They are also a common and important cause for seeking lay and professional advice (5). Unsurprisingly, this can lead to substantial losses in work performance (6-9). It seems that this is a universal problem, as the amount of lost working hours due to depression does not differ between European countries and is not associated with economic development or health coverage, but rather with other factors such as demographic and personality $(6,7)$. Taking into account that over $50 \%$ of depressed people are not identified and treated, we can easily imagine the far-reaching implications of this problem (8).

Previous studies have shown that almost one quarter of family practice patients suffer from depression and that depression correlates with female gender $(9,10)$, older age $(10)$, lower socioeconomic status $(10,11)$, lower level of education (3), and the presence of chronic diseases $(3,12)$. Less is known about the prevalence of depression in the working population, which is normally regarded as healthy. The prevalence of depression in the working 
population of some countries seems to vary between $5 \%$ and $10 \%$ (13-16). Possible risk factors for the development of depression in the working population include female gender, alcohol consumption, high psychological demands of a job, psychosocial work stressors, job insecurity, and drug abuse (17).

The aim of this study was to determine the prevalence of depression among the working population in Slovenia and identify factors that correlate with the higher prevalence of depression.

\section{METHODS}

\section{Study design, population, and data collection}

This was a multicentre, cross-sectional, observational study that took place in three Slovenian occupational medicine practices within primary health care centres in the towns of Maribor, Velenje, and Novo Mesto. Slovenian occupational medicine practices carry out check-ups prior to first employment and regular check-ups for the employed at five-year intervals.

This study was approved by the National Ethics Committee (approval No. 98/12/10), and all participants gave informed consent.

The study population consisted of individuals who visited occupational medicine practices for their regular occupational check-ups from November 2010 to June 2012. The inclusion criteria were the age from 18 to 64 years. The study included 1,696 respondents, but 222 were excluded due to incomplete data. The final sample consisted of 1,474 respondents, of whom $889(60.3 \%)$ were men and 585 (39.7\%) women.

Data were collected using a self-developed questionnaire completed by the participants. It consisted of information on demographics (gender, age, level of education, body height and weight), lifestyle [alcohol drinking (yes/no), smoking (yes/no), regular physical activity defined as at least half an hour of exercise at least three times a week (yes/no, and how many days of exercise per week), coffee drinking (yes/no, and how many cups per day)], selfperceived exposure to chronic stress (yes/no), chronic diseases (defined as the presence of any disease for at least six months), and family history of depression (defined as diagnosed depression in first, second, or third-degree relatives). The respondents could check a chronic disease on a list or write down a disease not included in the list.
Depression was assessed using the Zung self-rating depression scale (18). The scale consists of 20 depression-related statements. The questionnaire has been confirmed as a reliable measure of depression by several studies $(12,19,20)$. The statements on the Zung scale are scored on a four-point Likert scale. The total score (which is the sum of item scores) ranges from 20 to 80 points, and the total of $\geq 50$ points may indicate depression. According to Zung (18), 50 to 59 points is considered a mild depression, 60 to 69 moderate, and 70 and above severe.

\section{Statistical analysis}

The collected data were analysed with the SPSS 13.0 package (SPSS Inc, Chicago, IL). For statistical analysis, we divided the variable of "education" in two values: primary school and other levels of education. Descriptive statistics were computed. In the bivariate analysis, we used the chi-square test and independent $t$-test. In the multivariate analysis, we used logistic regression, which included all variables that resulted significant in the bivariate analysis. We considered $p<0.05$ as significant.

\section{RESULTS}

Table 1 shows the demographic characteristics of respondents.

While fifty $(3.4 \%)$ respondents scored higher than 50 points on the Zung scale, which is indicative of depression, the overall mean score $\pm \mathrm{SD}$ was $(34.5 \pm 7.7)$ points (Figure 1). Depression was significantly more common among the older workers

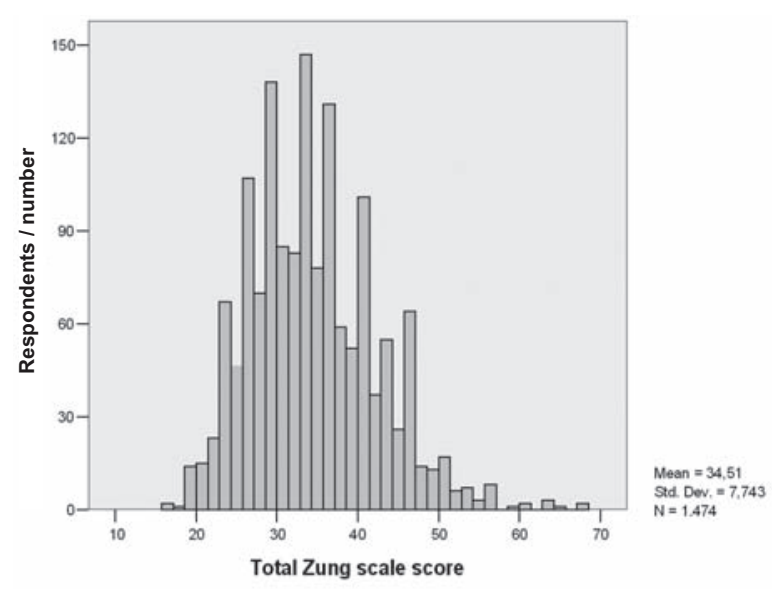

Figure 1 Histogram of the Zung self-rating depression scale scores 
Table 1 Respondent demographics

\begin{tabular}{|c|c|c|}
\hline Characteristic & Number & $\%$ \\
\hline \multicolumn{3}{|l|}{ Gender } \\
\hline Male & 889 & 60.3 \\
\hline Female & 584 & 39.7 \\
\hline \multicolumn{3}{|l|}{ Education } \\
\hline Primary school & 172 & 11.7 \\
\hline Vocational school & 555 & 37.7 \\
\hline Secondary school & 411 & 27.9 \\
\hline University & 245 & 16.6 \\
\hline No answer* & 91 & 6.1 \\
\hline Exercise regularly & 877 & 59.5 \\
\hline Drink alcohol & 207 & 14.0 \\
\hline Smoke & 390 & 26.5 \\
\hline Drink coffee & 1009 & 68.5 \\
\hline $\begin{array}{l}\text { See themselves as exposed to } \\
\text { chronic stress }\end{array}$ & 252 & 17.1 \\
\hline $\begin{array}{l}\text { Have a family history of } \\
\text { depression }\end{array}$ & 36 & 2.4 \\
\hline \multirow[t]{2}{*}{ Have a chronic disease } & 102 & 6.9 \\
\hline & \multicolumn{2}{|c|}{ Mean \pm SD } \\
\hline Age / year & \multicolumn{2}{|c|}{$40.5 \pm 9.8$} \\
\hline Body mass index $/ \mathrm{kg} \mathrm{m}^{-2}$ & \multicolumn{2}{|c|}{$26.9 \pm 4.5$} \\
\hline $\begin{array}{l}\text { Physical exercise / days per } \\
\text { week }\end{array}$ & \multicolumn{2}{|c|}{$3.0 \pm 0.5$} \\
\hline Coffee / cups per day & \multicolumn{2}{|c|}{$2.0 \pm 0.9$} \\
\hline
\end{tabular}

* excluded from correlation analysis

than among the younger [mean age (43.7 \pm 9.6$)$ years in workers with depression $v s$. (40.4 \pm 9.8$)$ years in workers without depression; independent $t$-test, $p=0.019]$. Depression was also significantly more common among workers who exercised less than three times a weak [mean $\pm \mathrm{SD}=(2.2 \pm 1.8)$ times a week] than those who exercised three or more times a week [(3.0 2.0$)$ times a week, independent $t$-test, $p=0.007]$. Positive family history of depression, female gender, primary education, self-perceived exposure to chronic stress, and chronic disease were also significantly associated with depression (Table 2).

In the multivariate analysis, the following variables independently correlated with depression (listed according to odds ratio): self-perceived exposure to chronic stress, positive family history of depression, and primary school education (Table 3 ).

\section{DISCUSSION}

The prevalence of depression in the working population from this study was $3.4 \%$. Respondents with self-perceived exposure to chronic stress, positive family history of depression, and primary education were more likely to report depression.

To the best of our knowledge, these are the first reported data on the prevalence of depression in the working population of Slovenia. Some studies on working populations from Central and Eastern Europe have reported associations between depression and various other factors, but have not reported on its prevalence $(21,22)$. In studies from other countries that did report these data, the prevalence of depression varied between $3 \%$ and $7 \%(14-16,23)$. One study in the Netherlands (23) reported cumulative 23-month incidence for depression of $3.3 \%$, while another study reported a prevalence of $7.1 \%$ for men and $6.2 \%$ for women (16). A Canadian study reported a 12-month prevalence of $6 \%$ (15), while in the US, 12-month prevalence of depression in the working population was $6.4 \%$ (14). It seems that differences in depression prevalence are not only due to methodological differences between the studies, but also due to differences between populations. These population differences suggest that depression is a disorder that results from complex genetic and environmental influences (24).

Our earlier study on the prevalence of chronic diseases in the general adult Slovenian population showed depression prevalence of almost $10 \%$ (25). In Slovenian family practice patients, the prevalence of depression was even higher - from $15 \%$ to $20 \%$ $(3,12,26)$. There could be several reasons for that. The first may be methodological. In previous Slovenian studies, the samples consisted of practice patients, which could have contributed to the higher bias. Namely, patients who visit practices do not necessarily represent the general population, as they may be ill and therefore more prone to depression. The difference could also be in different measurements of depression.

Another likely and even more important reason is that work in itself tends to provide gratification and the sense of being needed, as two important factors against depression.

However, the results of our study still point to the importance of taking family history in healthy working population at regular yearly check-ups. Screening for depression and other anxiety disorders in the working population should also include common chronic diseases, chronic exposure to stress, and lower education. 
Table 2 Bivariate correlations of depression and demographic characteristics

\begin{tabular}{|c|c|c|c|}
\hline Characteristic & \% of respondents with depression & Chi-square & $p$-value \\
\hline \multicolumn{4}{|l|}{ Genetic history } \\
\hline $\begin{array}{l}\text { Positive family history } v s . \text { negative } \\
\text { family history }\end{array}$ & 11.1 vs. 3.2 & 6.709 & 0.031 \\
\hline \multicolumn{4}{|l|}{ Demographic characteristics } \\
\hline Men vs. women & 2.1 vs. 5.3 & 10.808 & 0.002 \\
\hline $\begin{array}{l}\text { Primary school } v s . \text { other levels of } \\
\text { education }\end{array}$ & $7.0 v s .2 .6$ & 9.753 & 0.007 \\
\hline \multicolumn{4}{|l|}{ Lifestyle } \\
\hline $\begin{array}{l}\text { Self-perceived exposure to chronic } \\
\text { stress (yes/no) }\end{array}$ & 10.3 vs. 1.8 & 46.954 & $<0.001$ \\
\hline Regular physical activity (yes/no)* & 2.2 vs. 5.2 & 10.008 & 0.002 \\
\hline Alcohol (yes/no) & 1.4 vs. 3.6 & 2.578 & 0.139 \\
\hline Smoking (yes/no) & 2.8 vs. 3.6 & 0.539 & 0.517 \\
\hline Coffee (yes/no) & 3.3 vs. 3.8 & 0.265 & 0.640 \\
\hline \multicolumn{4}{|l|}{ Health status } \\
\hline Chronic disease (yes/no) & 8.8 vs. 3.0 & 9.865 & 0.006 \\
\hline
\end{tabular}

* This value presents the \% of respondents with depression who reported regular physical activity vs. \% of respondents with depression who reported not having any regular physical activity.

Table 3 Logistic regression for the presence of depression*

\begin{tabular}{|c|c|c|c|c|}
\hline $\begin{array}{l}\text { Dependent } \\
\text { variable }\end{array}$ & Independent variables & Odds ratio & $\begin{array}{l}95 \% \text { confidence interval for } \\
\text { odds ratio (lower, higher) }\end{array}$ & $p$-value \\
\hline \multirow{8}{*}{ Depression } & $\begin{array}{l}\text { Self-perceived exposure to chronic } \\
\text { stress }\end{array}$ & 6.308 & $3.081 ; 12.912$ & $<0.001$ \\
\hline & $\begin{array}{l}\text { Positive family history of } \\
\text { depression }\end{array}$ & 3.776 & $1.153 ; 12.367$ & 0.028 \\
\hline & Primary school education & 3.392 & $1.458 ; 7.892$ & 0.005 \\
\hline & Chronic disease & 1.233 & $0.458 ; 3.315$ & 0.679 \\
\hline & Age & 1.004 & $0.965 ; 1.045$ & 0.832 \\
\hline & Number of exercise days per week & 0.960 & $0.749 ; 1.230$ & 0.746 \\
\hline & Female gender & 0.712 & $0.348 ; 1.459$ & 0.354 \\
\hline & $\begin{array}{l}\text { Regular exercise (at least three } \\
\text { times per week } 30 \text { minutes) }\end{array}$ & 0.565 & $0.233 ; 1.368$ & 0.206 \\
\hline
\end{tabular}

${ }^{*}$ Chi-square $=50.402, d f=8, \mathrm{p}<0.001$, Nagelkerke $R^{2}=0.165$

The association between (parental) depression and offspring psychopathology has already been demonstrated (24), and the same is true for the association between depression and chronic diseases (3). Taking family history has been proposed as a useful tool to recognise increased risk of chronic illnesses (27-29). Furthermore, family history might also reflect the environmental conditions that favour the development of a certain disease. However, some of the associations with family history are likely to be spurious due to reporting biases of depressed individuals (30).
Chronic stress did not come as a surprise as an independent predictor of a higher prevalence of depression in our study. Chronic stress is an important cause of depression and anxiety $(26,31)$. As previous studies have shown, the working environment is an important source of long-term stress (32). Several studies in working populations have confirmed the association between exposure to stress and depression $(19,23,33)$. Although exposure to chronic stress in our study was not measured by objective tools, but was self-perceived by the respondents, its correlation 
with depression still provides important information. Self-reported exposure to stress may alone suffice to indicate whether a working population is prone to developing depression or not. Of course, to make an objective assessment, it is important to measure stressors at the workplace such as workload, control, and rewarding. However, self-perception could serve as an early indicator of increased risk of depression.

The association between lower education and depression has already been demonstrated in the general population $(12,26,34)$ and our study confirms that this association also holds true in the working population.

The main strength of this study is the inclusion of all regions of Slovenia. We stress this because Slovenia is geographically a very diverse country. The second strength of this study is the use of a validated tool for the identification of depressed individuals.

The biggest limitation of this study is that its crosssectional design does not show causal relationships. Another limitation concerns the problem of selfreporting. The data were not cross-checked with the workers' medical records or interviews with relatives and might be subject to bias. We also did not ask the respondents about the type of their profession, about their income levels, and exactly how distant were the relatives who suffered from depression.

\section{CONCLUSION}

Our study showed an unexpectedly low prevalence of depression in the Slovenian working population compared to other population groups. This suggests that being employed protects against depression, perhaps due to the feeling of being needed. Future prospective studies should look into the causal relationship between the working environment and depression, use this methodology to identify significant predictors for the development of common mental disorders in the working population, and establish the association between depression and family history or chronic stress on larger samples.

\section{Acknowledgements}

The authors would like to thank Marjanca Kamenik, the chief nurse at the Velenje Health Centre; Jože Zupančič, the director of the Velenje Health Centre; and Valentina Tasič, Alenka Simonič, and Miran Becner, head of occupational practices at the
Maribor Health Centre, for their help in collecting the data. This study was partly supported by the National Research Agency grant no. P3 0339.

\section{REFERENCES}

1. King M, Nazareth I, Levy G, Walker C, Morris R, Weich S, Bellón-Saameño JA, Moreno B, Svab I, Rotar D, Rifel J, Maaroos HI, Aluoja A, Kalda R, Neeleman J, Geerlings MI, Xavier M, de Almeida MC, Correa B, Torres-Gonzalez F. Prevalence of common mental disorders in general practice attendees across Europe. Br J Psychiatry 2008;192:362-7. doi: 10.1192/bjp.bp.107.039966

2. Salsberry PJ, Chipps E, Kennedy C. Use of general medical services among Medicaid patients with severe and persistent mental illness. Psychiatr Serv 2005;56:458-62. doi: 10.1176/ appi.ps.56.4.458

3. Klemenc-Ketis Z, Kersnik J, Novak-Glavac D. Determinants of depression and anxiety in family practice patients with comorbidities. Wien Klin Wochenschr 2010;122(Suppl 2):359. doi: 10.1007/s00508-010-1337-x

4. Eaton WW. Progress in epidemiology of anxiety disorders. Epidemiol Rev 1995;17:32-8. PMID: 8521944

5. Klemenc-Ketis Z, Kersnik J. Health seeking behaviour in general population with psychological symptoms. Psychiatr Danub 2013;25. IN PRINT

6. Veronese A, Ayuso-Mateos JL, Cabello M, Chatterii S, Nuevo R. Work disability and depressive disorders: impact on the European population. Am J Phys Med Rehabil 2012;91(Suppl 1):S62-8. doi: 10.1097/PHM.0b013e31823d4f02

7. Vlasveld MC, van der Feltz-Cornelis CM, Anema JR, van Mechelen W, Beekman AT, van Marwijk HW, Penninx BW. The associations between personality characteristics and absenteeism: a cross-sectional study in workers with and without depressive and anxiety disorders. J Occup Rehabil 2012 [Epub ahead of print] doi: 10.1007/s10926-012-94069

8. Ani C, Bazargan M, Hindman D, Bell D, Farooq MA, Akhanjee L, Yemofio F, Baker R, Rodriguez M. Depression symptomatology and diagnosis: discordance between patients and physicians in primary care settings. BMC Fam Pract 2008;9:1. doi: 10.1186/1471-2296-9-1

9. Piccinelli M, Wilkinson G. Gender differences in depression. Critical review. Br J Psychiatry 2000;177:486-92. doi: 10.1192/bjp.177.6.486

10. Merikangas KR, Pine D. Genetic and other vulnerability factors for anxiety and stress disorders. In: Davis KL, Charney D, Coyle JT, Nemeroff C, editors. Neuropsychopharmacology: the fifth generation of progress. Philadelphia: Lippincott Williams \& Wilkins; 2002. p. 86782.

11. Lorant V, Croux C, Weich S, Deliege D, Mackenbach J, Ansseau M. Depression and socio-economic risk factors: 7-year longitudinal population study. Br J Psychiatry 2007;190:293-8. doi: 10.1192/bjp.bp.105.020040

12. Klemenc-Ketis Z, Kersnik J, Tratnik E. The presence of anxiety and depression in the adult population of family practice patients with chronic diseases. Zdrav Var 2009;48:170-6 
13. Steward WF, Ricci JA, Chee E, Hahn SR, Morganstein D. Cost of lost productive work time among US workers with depression. JAMA 2003;289:3135-44. doi: 10.1001/ jama.289.23.3135

14. Kessler RC, Akiskal HS, Ames M, Birnbaum H, Greenberg P, Hirschfeld R, Jin R, Merikangas KR, Wang PS. The prevalence and effects of mood disorders on work performance in a nationally representative sample of US workers. Am J Psychiatry 2006;163:1561-8. doi: 10.1176/ appi.ajp.163.9.1561

15. Wang J, Smailes E, Sareen J, Fick GH, Schmitz N, Patten SB. The prevalence of mental disorders in the working population over the period of global economic crisis. Can J Psychiatry 2010;55:598-605. PMID: 20840807

16. Andrea H, Bültmann U, Beurskens AJ, Swaen GM, van Schayck CP, Kant IJ. Anxiety and depression in the working population using the HAD Scale - psychometrics, prevalence and relationships with psychosocial work characteristics. Soc Psychiatry Psychiatr Epidemiol 2004;39:637-46. doi: 10.1007/s00127-004-0797-6

17. Fushimi M, Saito S, Shimizu T. Prevalence of depressive symptoms and related factors in Japanese employees as measured by the Center for Epidemiologic Studies Depression Scale (CES-D). Community Ment Health J 2013;49:236-42. doi: 10.1007/s10597-012-9542-x

18. Zung WW. A self-rating depression scale. Arch Gen Psychiatry 1965;12:63-70. doi: 10.1001/ archpsyc. 1965.01720310065008

19. Murcia M, Chastang JF, Niedhammer I. Psychosocial work factors, major depressive and generalised anxiety disorders: Results from the French national SIP study. J Affect Disord 2013;146:319-27. doi: 10.1016/j.jad.2012.09.014

20. Stansfeld S, Candy B. Psychosocial work environment and mental health - a meta-analytic review. Scand J Work Environ Health 2006;32:443-62. doi:10.5271/sjweh.1050

21. Pikhart H, Bobak M, Pajak A, Malyutina S, Kubinova R, Topor R, Sebakova H, Nikitin Y, Marmot M. Psychosocial factors at work and depression in three countries of Central and Eastern Europe. Soc Sci Med 2004;58:1475-82. PMID: 14759691

22. Nicholson A, Pikhart H, Pajak A, Malyutina S, Kubinova R, Peasey A, Topor-Madry R, Nikitin Y, Capkova N, Marmot M, Bobak M. Socio-economic status over the life-course and depressive symptoms in men and women in Eastern Europe. J Affect Disord 2008;105:125-36. PMID: 17561267

23. Andrea H, Bültmann U, van Amelsvoort LG, Kant Y. The incidence of anxiety and depression among employees--the role of psychosocial work characteristics. Depress Anxiety 2009;26:1040-8. doi: 10.1002/da.20516
24. Sullivan PF, Neale MC, Kendler KS. Genetic epidemiology of major depression: review and meta-analysis. Am J Psychiatry 2000;157:1552-62. doi: 10.1176/appi. ajp.157.10.1552

25. Softic N, Smogavec M, Klemenc-Ketis Z, Kersnik J. Prevalence of chronic diseases among adult Slovene population. Zdrav Var 2011;50:185-90.

26. Selič P, Svab I, Rifel J, Pavlič DR, Černe A, King M, Nazareth I. The pattern of physical comorbidity and the psychosocial determinants of depression: a prospective cohort study on a representative sample of family practice attendees in Slovenia. Ment Health Fam Med 2011;8:147-55. PMID: 22942896

27. Yoon PW, Scheuner MT, Jorgensen C, Khoury MJ. Developing family healthware, a family history screening tool to prevent common chronic diseases. Prev Chronic Dis 2009;6:A33.

28. Lieb K, Brandtönies S. A Survey of german physicians in private practice about contacts with pharmaceutical sales representatives. Dtsch Arztebl Int 2010;107:392-8. doi: 10.3238/arztebl.2010.0392

29. Scheuner MT, Raffel LJ, Larabell SK, Rotter JI. Family history: a comprehensive genetic risk assessment for chronic conditions of adulthood. Am J Med Genet 1997;71:315-24. PMID: 9268102

30. Kendler KS, Silberg JL, Neale MC, Kessler RC, Heath AC, Eaves LJ. The family history method: whose psychiatric history is measured? Am J Psychiatry 1991;148:1501-4. PMID: 1928463

31. Griffin JM, Fuhrer R, Stansfeld SA, Marmot M. The importance of low control at work and home on depression and anxiety: do these effects vary by gender and social class? Soc Sci Med 2002;54:783-98. doi: 10.1016/S02779536(01)00109-5

32. Brešić J, Knežević B, Milošević M, Tomljanović T, Golubović R, Mustajbegović J. Stress and work ability in oil industry workers. Arh Hig Rada Toksikol 2007;58:399-405. doi: 10.2478/v10004-007-0032-4

33. Avčin BA, Kučina AU, Sarotar BN, Radovanović M, Plesničar BK. The present global financial and economic crisis poses an additional risk factor for mental health problems on the employees. Psychiatr Danub 2011;23(Suppl 1):S142-8. PMID: 21894123

34. Ostergaard SD, Waltoft BL, Mortensen PB, Mors O. Environmental and familial risk factors for psychotic and non-psychotic severe depression. J Affect Disord 2013;147:232-40. doi: 10.1016/j.jad.2012.11.009 


\section{Povzetek}

\section{PRISOTNOST DEPRESIJE IN NJENE POVEZAVE V SLOVENSKI DELOVNI POPULACIJI}

Namen raziskave je bil določiti prevalence depresije med delovno aktivno populacijo in odkriti morebitne dejavnike, povezane z večjo prevalence depresije. Izvedli smo multicentrično presečno opazovalno raziskavo $\mathrm{v}$ ambulantah medicine dela, prometa in športa $\mathrm{v}$ treh večjih zdravstvenih domovih v Sloveniji. Opazovana populacija je bila sestavljena iz zaporednih obiskov delavcev, ki so prišli na redni preventivni pregled od novembra 2010 do junija 2012. Podatke smo zbirali s pomočjo vprašalnika, depresijo pa smo ugotavljali na podlagi Zungovega vprašalnika. V vzorcu je bilo 1.474 (73,7 \%) posameznikov, od katerih je bilo 889 $(60,3$ \%) moških. Povprečna starost vzorca je bila $(40,5 \pm 9,8)$ let. V vzorcu je bilo $590(3,4 \%)$ posameznikov $\mathrm{z}$ depresijo. $\mathrm{V}$ multivariatni analizi so bile naslednje spremenljivke neodvisno povezane s prisotnostjo depresije: izpostavljenost stresu, pozitivna družinska anamneza depresije in osnovnošolska izobrazba.

KLJUČNE BESEDE: delavci, duševne bolezni, presečna raziskava, prevalence, primarno zdravstvo

\section{CORRESPONDING AUTHOR:}

\section{Zalika Klemenc-Ketiš}

Kersnikova 1, Velenje, Slovenia

Email: zalika.klemenc-ketis@uni-mb.si 